\title{
Potential of the Ethanolic Extract of Matoa Leaves (Pometia pinnata J.R. \& G.Forst) against Staphylococcus aureus bacteria
}

\section{Potensi Ekstrak Etanol Daun Matoa (Pometia pinnata J.R. \& G.Forst) terhadap Bakteri Staphylococcus aureus}

\author{
Wahyu Margi Sidoretno \\ Fakultas Farmasi dan Ilmu Kesehatan, Universitas Abdurrab \\ Email : wahyu.margi@univrab.ac.id
}

Article Info

Article history

Received date: 2022-01-20

Revised date: 2022-01-30

Accepted date: 2022-02-02

\begin{abstract}
Matoa (Pometia pinnata J.R. \& G. Forst) leave extract contained phenolic and flavonoid compounds that known has antibacterial activity. The activity was investigated for positive gram bacteria Staphylococcus aureus by analyzing inhibition zone using disk diffusion method. The experiment was carried out using Mueller Hinton Agar (MHA) and ciprofloxacin as positive control. The disk diffusion method revealed the inhibition zones for 10\%, 20\%, and $30 \%$ concentration of extract were $11.06 \mathrm{~mm}, 15.07 \mathrm{~mm}, 16.07 \mathrm{~mm}$, respectively with positive control was $28.10 \mathrm{~mm}$. Based on the results, it can be concluded that Matoa leave extracts have potential against Staphylococcus aureus.

Keywords:

Antibacterial Activity; Pometia pinnata; Staphylococcus aureus

\section{Abstrak}

Daun matoa mengandung senyawa fenolik dan flavonoid yang diketahui mempunyai khasiat sebagai antibakteri. Tujuan dari penelitian ini adalah untuk mengetahui aktivitas antibakteri ekstrak etanol daun matoa Pometia pinnata J.R.\& G.Forst terhadap bakteri Staphylococcus aureus pada konsentrasi $10 \%$, $20 \%$, dan $30 \%$. Staphylococcus aureus merupakan bakteri yang dapat mengakibatkan beberapa penyakit pada manusia seperti bisul dan infeksi pada luka. Penelitian ini dilakukan dengan metode difusi cakram pada media Mueller Hinton Agar (MHA). Aktivitas antibakteri diukur dengan melihat daya hambat pertumbuhan bakteri S. aureus. Berdasarkan hasil penelitian didapatkan bahwa ekstrak etanol daun matoa mampu menghambat pertumbuhan bakteri S. aureu dengan rata-rata zona hambat yang dihasilkan konsentrasi $10 \%, 20 \%$ dan $30 \%$ yaitu $11,06 \mathrm{~mm}, 15,07 \mathrm{~mm}, 16,07 \mathrm{~mm}$ dan kontrol positif siprofloksasin adalah 28,10 $\mathrm{mm}$. Dari hasil diatas dapat diambil kesimpulan bahwa ekstrak etanol daun matoa (Pometia pinnata) memiliki aktivitas antibakteri terhadap Staphylococcus aureus.
\end{abstract}

Kata Kunci

Aktivitas antibakteri, Pometia Pinnata, Staphylococcus aureus

\section{PENDAHULUAN}

Tanaman matoa merupakan tanaman suku Sapindaceae yang tersebar di daerah tropis termasuk Indonesia. Manfaat dari tanaman matoa yaitu kulit kayu dipakai masyarakat Priangan untuk mengobati luka, daun yang besar digunakan sebagai mulsa pada penanaman gembili atau gandum.

Rebusan daun dan kulit kayu dipakai mandi untuk mengatasi demam. Masyarakat Fiji menggunakan ekstrak daun untuk menghitamkan rambut, rendaman daun di air panas baik untuk mengobati disentri [1]. 
Ekstrak daun Pometia pinnata J.R.\& G.Forst mampu menghambat virus HIV-1 IN [2]. Berdasarkan penelitian Martiningsih (2016) daun matoa mengandung senyawa fenolik dan flavonoid. Senyawa fenolik merupakan senyawa aktif metabolit sekunder yang diketahui mempunyai khasiat sebagai antibakteri [3].

Staphylococcus aureus adalah bakteri Gram positif yang berbentuk kokus mengelompok seperti anggur dan merupakan floura normal pada manusia (saluran hidung, kulit dan membran mukosa) serta dapat bersifat patogen yang menyebabkan infeksi. Infeksi Staphylococcus aureus dapat disebabkan penularan melalui tangan ke tempat bakteri, misalnya luka yang ada pada kulit, luka pasca bedah dan luka lainnya [4]

Berdasarkan beberapa penelitian sebelumnya tentang pengaruh antibakteri ekstrak kulit batang matoa Pometia pinnata J.R.\& G.Forst terhadap bakteri Staphylococcus aureus secara in vitro bahwa kulit batang matoa memiliki pengaruh yang kuat sebagai antibakteri [5]. Pada penelitian yang dilakukan [6] tentang efektivitas daya antibakteri ekstrak daun matoa Pommetia pinnata J. R. \& G.Forst dalam berbagai konsentrasi terhadap pertumbuhan Streptococcus mutans (secara in vitro) telah terbukti daun matoa efektif menghambat bakteri Streptococcus mutans pada konsentrasi $25 \%$, $50 \%$, dan $75 \%$. Penelitian ini ditujukan untuk sebagai dasar penelitian selanjutnya yang dapat digunakan untuk penelitian formulasi sediaan farmasi yang ditujukan sebagai antibakteri.

\section{METODE}

Penelitian ini merupakan penelitian eksperimental untuk menentukan aktivitas antibakteri ekstrak etanol daun matoa terhadap Staphylococcus aureus. Aktivitas antibakteri ditandai dengan terbentuknya zona hambat berwarna bening pada media yang digunakan. Sampel daun matoa diambil di daerah perumahan Jl. Garuda Sakti KM 27 Desa Pantai Cermin, Kampar, Riau yang telah dilakukan identifikasi di Laboratorium Botani FMIPA Universitas Riau. Penelitian dilakukan di Laboratorium Mikrobiologi Universitas Abdurrab di Pekanbaru.

Alat yang digunakan dalam penelitian ini adalah beker glass (Iwaki), timbangan analitik, kaca arloji, autoklaf (Memmert), batang pengaduk, kawat ose, cawan petridish (Iwaki), erlenmeyer (Iwaki), gelas ukur (Iwaki), Inkubator (Memmert), lampu spritus, kaki tiga penyangga, asbes, labu ukur (Iwaki), oven (Memmert), rotary evaporator (EYELA), jangka sorong (Kenmaster), pipet volume (Iwaki), gelas ukur (Iwaki), pipet mikro, tabung reaksi (Iwaki), rak tabung reaksi.

Bahan yang digunakan pada penelitian ini adalah simplisia Daun Matoa, aquades, dimethysulfoxide (DMSO), $\mathrm{NaCl}$ fiosiologis steril, etanol $96 \%$, alkohol $70 \%$, disk kosong, disk siprofloksasin, strain Staphylococcus aureus, Media MHA (muller hinton agar), kapas steril.

Pembuatan ekstrak etanol daun matoa. Ekstrak etanol daun matoa dibuat dengan cara simplisia yang telah kering diserbukkan dan ditimbang sebanyak 500 gram, kemudian dimaserasi menggunakan pelarut etanol 96\% hingga terendam, selama 24 jam

Dengan sesekali diaduk atau dikocok. Pisahkan maserat dengan cara filtrasi. Proses dilakukan selama 3 hari sampai larutan menjadi jernih. Kumpulkan semua maserat, kemudian diuapkan dengan rotary evaporator hingga diperoleh ekstrak kental daun matoa [7]. Pada pembuatan larutan ekstrak etanol daun matoa konsentrasi $30 \%$ dilakukan dengan cara timbang sebanyak 3 gram ekstrak kemudian di larutkan dengan DMSO didalam labu ukur $10 \mathrm{ml}$, kemudian 
dihomogenkan. Konsentrasi 20\% dibuat dengan menimbang ektrak etanol sebanyak 2 gram dan dilarutkan dengan DMSO pada labu ukur $10 \mathrm{ml}$, begitu selanjutnya dengan konsentrasi $10 \%$.

Pembuatan media MHA (Mueller Hinton Agar) dilakukan dengan cara menimbang media sebanyak 3,8 gram kemudian dimasukkan dalam erlenmeyer $250 \mathrm{ml}$ yang telah disterilkan dilarutkan dengan akuades $100 \mathrm{~mL}$, kemudian dipanaskan sampai mendidih, setelah mendidih tutup permukaan erlenmeyer dengan kain kasa yang berisi kapas. Kemudian media disterilkan menggunakan autoklaf pada suhu $121^{\circ} \mathrm{C}$ selama 15 menit. Setelah proses sterilisasi, media dikeluarkan dari autoklaf setelah itu media didiamkan hingga suhu nya $\pm 50^{\circ} \mathrm{C}$ (hangat), setelah itu media dituangkan ke dalam masing-masing cawan petri sebanyak $\pm 60 \mathrm{~mL}$ lalu didiamkan hingga membeku, setelah media didalam cawan petri membeku media dapat digunakan untuk pengujian [8].

Pembuatan larutan standar Mc.Farland, larutan standart Mc. Farland terdiri dari larutan $\mathrm{H}_{2} \mathrm{SO}_{4} 1 \%$ dan $\mathrm{BaCl}_{2} 1 \%$. Cara pembuatannya yaitu, $\mathrm{H}_{2} \mathrm{SO}_{4} 1 \%$ dipipet sebanyak $9 \mathrm{~mL}$ dicampurkan dengan larutan $\mathrm{BaCl}_{2} 1 \%$ sebanyak $1 \mathrm{~mL}$ kemudian dimasukkan kedalam tabung reaksi. Setelah itu dikocok sampai terbentuk larutan yang keruh. Kekeruhan ini dipakai sebagai standar kekeruhan suspensi bakteri uji [9].

Pembuatan suspensi bakteri dilakukan dengan cara disiapkan kawat ose yang steril, kemudian bakteri Staphylococcus aureus yang telah diinokulasi diambil dengan ujung kawat ose, setelah itu disuspensikan kedalam tabung yang berisi $10 \mathrm{~mL}$ larutan $\mathrm{NaCl}$ fisiologis hingga diperoleh kekeruhan yang sama dengan standar kekeruhan larutan Mc. Farland.

Suspensi Staphylococcus aureus dioleskan pada permukaan media secara zigzag menggunakan kapas lidi steril, sampai semua bagian media rata terolesi. Kemudian kertas disk kosong diletakkan pada permukaan media dan diteteskan $10 \mu \mathrm{L}$ ekstrak etanol daun matoa konsentrasi $10 \%, 20 \%$ dan $30 \%$ dengan diberi tekanan. Kertas disk kosong diletakkan di tengah cawan petri pada permukaan media dan diteteskan dengan DMSO steril sebagai kontrol negatif (-). Kertas disk siprofloksasin diletakkan di bagian pinggir kanan cawan petri pada permukaan media sebagai kontrol positif $(+)$. Pengulangan dilakukan sebanyak 3 kali kemudian diinkubasi selama $1 \times 24$ jam pada suhu $37^{\circ} \mathrm{C}$ dan diukur zona bening yang berada disekitar disk [10].

\section{HASIL DAN PEMBAHASAN}

Hasil yang diperoleh dari pengujian aktivitas antibakteri ekstrak etanol daun matoa dapat dilihat pada tabel dibawah ini;

Tabel 1. Hasil pengukuran diameter zona hambat ekstrak etanol daun matoa terhadap Staphylococcus aureus $(\mathrm{mm})$

\begin{tabular}{lcccc}
\hline & \multicolumn{4}{c}{ Diameter zona hambat $(\mathrm{mm})$} \\
\hline Kelompok & $\mathrm{I}$ & $\mathrm{II}$ & III & $\begin{array}{c}\text { Rata- } \\
\text { rata }\end{array}$ \\
\hline Konsentrasi 10\% & 10,07 & 10,07 & 11,06 & 10,4 \\
Konsentrasi $20 \%$ & 17,58 & 16,05 & 16,59 & 16,74 \\
Konsentrasi $30 \%$ & 17,61 & 16,55 & 18,06 & 17,41 \\
Kontrol (+) & 27,17 & 28,05 & 27,10 & 27,44 \\
Kontrol (-) & 0 & 0 & 0 & 0 \\
\hline
\end{tabular}

Penelitian ini dilakukan secara in vitro menggunakan ekstrak daun matoa. Konsentrasi perlakuan yang digunakan adalah konsentrasi bertingkat dan di ulang menjadi tiga kali perlakuan, menggunakan dua kelompok kontrol yaitu kontrol positif dan kontrol negativ. Kelompok kontrol negative diberikan DMSO 
dan dikelompok kontrol positif yang digunakan adalah siprofloksasin. Tujuan penelitian ini adalah mengetahui aktivitas antibakteri dari ektrak etanol daun matoa terhadap Staphylococcus aureus. Sampel daun matoa yang diambil dipekarangan rumah dan telah dilakukan identifikasi di Laboratorium Botani FMIPA Universitas Riau. Daun matoa yang segar dilakukan sortasi basah dan dilanjutkan dengan sortasi kering sehingga didapatkan simplisia yang memiliki mutu baik. Simplisia yang bermutu baik adalah jika simplisianya daun, maka bila diremas bergemerisik dan berubah jadi serpihan, tidak berjamur, berbau khas menyerupai daun segarnya, berasa khas seperti bahan segarnya [11].

Daun matoa memiliki kandungan senyawa alkaloid, flavonoid, tannin, saponin, dan triterpenoid yang dapat berkhasiat sebagai antibakteri [12]. Lely et al., (2016) juga melakukan penelitian terhadap ekstrak etanol dan beberapa fraksi daun matoa. Dari hasil penelitiannya daya hambat terhadap Staphylococcus aureus yang terbesar adalah pada ekstrak etanol daun matoa (Pometia pinnata) [13]. Pengujian aktivitas antibakteri ekstrak etanol batang matoa dilakukan (Ngajow et al., 2013) hasil penelitiannya menunjukan bahwa ekstrak etanol batang matoa dapat menghambat bakteri Staphylococcus aureus [14].

Sampel diekstraksi dengan metode maserasi menggunakan pelarut etanol $96 \%$. Penggunaan etanol $96 \%$ sebagai pelarut ekstraksi ini kerena etanol mampu melarutkan hampir senyawa organik dalam daun matoa baik polar, semi polar, maupun non polar. Selain itu etanol mempunyai titik didih yang cukup rendah $\left(64,5^{\circ} \mathrm{C}\right)$ sehingga lebih mudah divapkan [15].

Bakteri Staphylococcus aureus disuspensikan dalam larutan $\mathrm{NaCl}$ fisiologis sampai kekeruhannya sama dengan larutan Mc. Farland. Kekeruhan yang sama dengan larutan Mc.Farland diasumsikan jumlah mikroba uji pada media tidak terlalu rapat dan tidak terlalu jarang. Karena standar kekeruhan Mc. farland ini dimaksudkan untuk menggantikan perhitungan bakteri satupersatu dengan memperkirakan kepadatan sel yang akan digunakan pada prosedur pengujian anti mikroba [16]

Penelitian ini menggunakan media Mueller Hinton Agar (MHA) pemilihan media media ini merupakan media universal yang kaya akan nutrisi untuk pertumbuhan bakteri serta media ini telah direkomendasikan oleh Foods and Drugs Administration (FDA) dan World Health Organization (WHO) untuk tes antibakteri [17]. Pada saat penanaman bakteri pada media Mueller Hinton Agar (MHA), perlu diperhatikan bahwa suspensi bakteri harus kekeruhannya setara dengan standar Mc. Farland. Suspensi bakteri dioles merata pada permukaan media menggunakan lidi kapas steril.

Pada penelitian ini kontrol negatif yang digunakan adalah DMSO Dimetil sulfoksida), merupakan cairan yang tidak bewarna dan bersifat inert. Pemilihan DMSO sebagai pelarut didasarkan pada kemampuanya untuk melarutkan berbagai senyawa baik yang bersifat polar maupun non polar, khususnya peptida. Selain itu juga memiliki kemampuan untuk menembus membran sel. DMSO juga digunakan untuk melarutkan sampel uji.

Pada penelitian ini kontrol positif yang digunakan adalah siprofloksasin. Pemilihan siprofloksasin sebagai kontrol positif (+) karena siprofloksasin merupakan antibiotik berspektrum kerja luas pada organisme Gram positif dan Gram negatif sehingga dapat menghambat pertumbuhan bakteri uji yang digunakan [18].

Proses inkubasi dilakukan selama 24 jam pada suhu $37^{\circ} \mathrm{C}$. setelah itu dilakukan pengukuran zona bening menggunakan jangka sorong. Setelah data diperoleh 
kemudian data dirata-ratakan berdasarkan konsetrasi sampel dan pengulangan.

Hasil pengukuran zona hambat pada konsentrasi $10 \%$ sebesar $10,04 \mathrm{~mm}$,

konsentrasi $20 \%$ sebesar 16,74 $\mathrm{mm}$, konsentrasi $30 \%$ sebesar $17,41 \mathrm{~mm}$. Pembuatan sampel uji dilakukan dengan menimbang masing-masing konsentrasi kemudian dilarutkan dengan DMSO didalam labu ukur $10 \mathrm{~mL}$ pada kontrol positif diperoleh zona hambat 27,44 $\mathrm{mm}$. Berdasarkan hasil tersebut dapat dinyatakan bahwa ekstrak etanol daun matoa memiliki aktivitas antibakteri. Lebar diameter zona hambat yang terbentuk dapat dijadikan sebagai parameter untuk melihat kekuatan senyawa bioaktif yang terkandung dalam ekstrak daun matoa. Semakin lebar zona hambat yang terbentuk mengindikasikan bahwa semakin kuat senyawa bioaktif menghambat pertumbuhan bakteri [19].

\section{SIMPULAN}

Berdasarkan dari hasil penelitian yang telah dilakukan, ekstrak etanol daun matoa (Pometia pinnata J. R. \& G. Forst) terhadap bakteri Staphylococcus aureus dapat disimpulkan bahwa daun matoa memiliki aktivitas antibakteri terhadap bakteri Staphylococcus aureus. Hasil yang didapatkan berdasarkan pengukuran tinggi, sedang dan rendah dengan konsentrasi 10 $\%$, $20 \%$ dan $30 \%$ rata-rata yang didapatkan dari hasil pengukuran zona hambat yaitu, $11,06 \mathrm{~mm}, 15,07 \mathrm{~mm}, 16,07$ $\mathrm{mm}$. sehingga dapat disimpulkan bahwa semakin tinggi konsentrasi maka semakin besar aktivitas antibakteri ekstrak etanol daun matoa tersebut.

\section{UCAPAN TERIMA KASIH}

Terimakasih kepada Lembaga Penelitian dan Pengabdian (LPPM) Universitas Abdurrab, yang telah memfasilitasi pelaksanaan penelitian ini.

\section{DAFTAR PUSTAKA}

[1] Suharno, H.R Tanjung. Matoa, Yogyakarta, 2011

[2] Suedee, A, Phytocemichal Studies of Mimusopselengi and Pometia pinnata Leaf Extract with Anti HIV 1 Integrase Activity. Thesis. Songkla (TH): Prince of Songkla University, 2012

[3] Martiningsih, N. W., Widana, G. A. B., dan Kristiyanti, P. L. P, Skrining Fitokimia dan Uji Aktivitas Antioksidan Ekstrak Etanol Daun Matoa (Pometia pinnata) dengan Metode DPPH. Prosiding Seminar Nasional MIPA. Halaman $332-338,2016$

[4] Soedarto, Mikrobiologi Kedokteran. Jakarta: Sagung Seto, 2015

[5] Ngajow, M., Abidjulu, J., dan Kamu, V. $S$, Pengaruh Antibakteri Ekstrak Kulit Batang Matoa (Pometia pinnata) Terhadap Bakteri Staphylococcus aureus secara In vitro, Jurnal MIPA UNSRAT, Volume 2 (2): Halaman 128 - 132, 2013

[6] Zanuary, A.R., Efektivitas Daya Antibakteri Ekstrak Daun Matoa (Pometia Pinnata J. R. \& G. Forst) Dalam Berbagai Konsentrasi Terhadap Pertumbuhan Streptococcus Mutans (secara invitro): Semarang, 2014

[7] Departemen Kesehatan Republik Indonesia, Suplemen 1 Farmakope Herbal Indonesia. Direktorat Jendral Pengawasan Obat dan Makanan, Jakarta, 2010

[8] Thermo Fisher Scientific, Dehydrated Culture Media, Mueller Hinton Agar, CM0337, OXOID, 2022

[9] Aryal, S. McFarland Standar-Principle, Preparation, Uses, Limitattions, Microbe Notes, 2021

[10] Torar, G.M.J., W.A. Lolo, dan G. Citraningtyas, Uji Aktivitas Antibakteri 
Ekstrak Etanol Biji Pepaya (Carica papaya L.) terhadap Bakteri Pseudomonas aeruginosa dan Staphylococcus aureus. Jurnal Ilmiah Farmasi, Vol. 6 No. 2, 2017

[11] Herawati, D. L.N, Sumarto, Cara Produksi Simplisia yang Baik, Bogor: Seafast Center, IPB, 2012

[12] Kuspradini, Harlinda., Pasedan, Whicliffe Fiernaleonardo Pasedan., \&Wijaya, Irawan. Aktivitas Antioksidan dan Antibakteri Ekstrak Daun Pometia pinnata. Jurnal Jamu Indonesia. 1 (1):26-34, 2016

[13] Lely, Nilda., Ayu, Anestia Meta \& Adrimas. Efektifitas Fraksi Daun Matoa (Pometia pinnata J.R. Forst. \& G. Forst.) Sebagai Antimikroba. Jurnal Ilmiah Bhakti Farmasi, 1 (1), 2016

[14] Ngajow, Mercy., Abidjulu, Jemmy \& Vanda S. Kamu. Pengaruh Antibakteri Ekstrak Etanol Kulit Batang Matoa (Pometia pinnata) terhadap Staphylococcus aureus. Jurnal MIPA UNSRAT, Online 2 (2), 2013
[15] Tanaya, V., R. Retnowati dan Suratmo, Fraksi Semi Polar dari Daun Mangga Kasturi (Mangifera casturi Kosterm). Kimia Student Journal, Vol 1 No 1. Universitas Brawijaya, 2015

[16] Sutton, S, Measurement of Microbial Cells Bay Optial Density. Journal of Validation Technology. 17: 46-49, 2011

[17] Acumedia, Muller Hinton Agar, PI 7101. Rev 03, 2011

[18] Kee, J.L dan E. R. Hayes, Farmakologi Pendekatan Proses Keperawatan, Jakarta: Buku Kedokteran EGC, 1996

[19] Kaharap, A.D, Mambo C., dan Nangoy E, Uji Efek Antibakteri Ekstrak Batang Akar Kuning (Arcangelista lava Merr) terhadap Bakteri Staphylococcus aureus dan Escherichia coli. Jurnal eBiomedik (eBm), Volume 4, Nomor 1. Universitas sam Ratulangi Manado, 2016 